\title{
Farmers in Côte d'Ivoire value integrating tree diversity in cocoa for the provision of ecosystem services
}

\author{
E. Smith Dumont • G. M. Gnahoua $\cdot$ L. Ohouo • \\ F. L. Sinclair $\cdot$ P. Vaast
}

Received: 10 September 2013/Accepted: 21 February 2014/Published online: 20 March 2014

(C) The Author(s) 2014. This article is published with open access at Springerlink.com

\begin{abstract}
Côte d'Ivoire produces $40 \%$ of the world supply of cocoa but much of the plantation area is aging and declining in productivity, while opportunities for land expansion into new forest land are quickly disappearing. Rejuvenation strategies for cocoa presently coalesce either around improved varieties and greater use of agro-chemical inputs in full sun systems or eco-certification that requires trees to be integrated with cocoa. Here, we explore the possibility of uniting
\end{abstract}

E. Smith Dumont $(\bowtie) \cdot$ F. L. Sinclair · P. Vaast World Agroforestry Centre (ICRAF), United Nations Avenue, Gigiri, PO Box 30677-00100, Nairobi, Kenya e-mail: e.smith@cgiar.org

E. Smith Dumont · F. L. Sinclair

Bangor University, Bangor, Gwynedd LL57 2DG, UK

G. M. Gnahoua

Centre National de Recherche Agronomique (CNRA), Programme Forêt et Environnement, 08 BP 33,

Abidjan 08, Côte d'Ivoire

L. Ohouo

World Agroforestry Centre (ICRAF), Cocody Mermoz, Avenue 908 BP 2823, Abidjan 08, Côte d'Ivoire

P. Vaast

Centre de Cooperation Internationale en Recherche Agronomique pour le Développement (CIRAD), UMR Eco\&Sols - Ecologie Fonctionnelle \& Biogéochimie des Sols \& Agroécosystèmes, 2 Place Viala,

34060 Montpellier cedex 2, France these approaches through building on current farmer practice of incorporating trees in their cocoa fields to improve cocoa productivity and diversify their livelihoods. We interviewed 355 farmers about trees integrated in their cocoa fields across four locations in the South-West of Côte d'Ivoire in 2012, stratified by whether or not farmers were eco-certified. Despite the massive deforestation, a rich diversity of trees was found in cocoa fields and an overwhelming majority of farmers $(95 \%)$ wanted more trees and/or more tree species, regardless of their certification status or ethnic origin. There was a consensus that most trees were compatible with cocoa, but farmers also traded off negative impacts of some species against their productive contribution to their livelihood. Farmers valued tree diversity on their cocoa plots and provided detailed information on how 32 tree species interacted with cocoa in terms of soil moisture retention, soil fertility improvement and pest and disease interactions but also had key gaps in knowledge about alternative hosts of mirids and mistletoe. The majority of farmers were not aware of the certification requirements for tree species and shade cover but a much higher proportion of certified farmers $(76 \%)$ had received information about shade trees than non-certified farmers (15\%), although advice only related to eight tree species. Scope for building on local knowledge and practice to sustainably increase cocoa productivity through promoting tree diversity while enhancing other ecosystem service provision was identified and the next steps required to realize this set out. 
Keywords Agroforestry - Eco-certification · Shade - Tree diversity - Tree suitability . Local knowledge

\section{Introduction}

Côte d'Ivoire produces $40 \%$ of the world's cocoa, an important global commodity, with an annual value of over 10 billion USD of unprocessed beans (World Cocoa Foundation 2012). The economic and political significance of cocoa is of great importance for the country; not only as a key source of foreign exchange revenue but also as a cash crop grown by 700,000 smallholders and sustaining the livelihoods of over four million people (Mission économique 2005). In the South-West of Cote d'Ivoire, over the last forty years, the growth of the cocoa sector, driven by a favorable policy environment, has attracted a large influx of migrants from neighboring countries and led to the massive destruction of large parts of the Guinea Rainforest, a global biodiversity hotspot (Clough et al. 2009; Gockowski et al. 2004). Ivorian forest cover was estimated to be 14.5 million ha in 1900, reduced to 9 million ha in 1965 and to 2.5 million ha in 1992 (Oszwald 2005). The severe impacts of widespread cocoa-led deforestation on the provision of ecosystem services, including biodiversity loss, has raised significant concern, notably amongst conservationists, about the sustainability of cocoa land use (Rice and Greenberg 2000; Schroth and Harvey 2007; Clough et al. 2009). Historically, cocoa production in Côte d'Ivoire has increased by extending the cultivated area and taking advantage of soil fertility built up under forest cover (Ruf and Zadi 1998). Today, in West Africa and particularly Côte d'Ivoire, declining yields, resulting from ageing cocoa fields with low fertility, pest and disease problems, coupled with scarcity of forest are posing severe challenges to both the farmers and the industry (Ruf 2011; Tscharntke et al. 2011). Concerns over the future supply of cocoa to meet a predicted annual increase in world demand of 2-3\% has prompted the industry and governments in West Africa to support research and development activities aimed at rejuvenating ageing fields to increase their productivity (Asare 2005).

Cocoa is traditionally grown in agroforestry systems with permanent shade management resulting from thinning the original forest canopy and retaining a diversity of trees, planting useful fruit and timber species as well as protecting valuable trees from natural regeneration. Although complex multi-strata shaded systems still prevail in Cameroon and parts of Nigeria, there has been an increasing move in West Africa towards intensification of cocoa management with shade removal and monoculture practices (Gockowski et al. 2004; Ruf 2011). In the South-West of Cote d'Ivoire, the majority of cocoa farms were established on forestland, mainly planted with unselected cocoa genetic material and a mixture of Amelonado and hybrids, temporarily established under Musa spp. shade and predominantly managed with low shade or no shade (Gockowski and Sonwa 2011; Sonwa et al. 2014). Agricultural extension services in Côte d'Ivoire have traditionally promoted intensive systems in full sun to maximize short-term yield (N'Goran, 1998; Asare 2005). Complete forest clearance was encouraged (Ruf and Zadi 1998) and a list of 45 forest tree species identified that should not be associated with cocoa for a number of antagonistic reasons such as pest and disease relationships, allellopatic behavior, or low shade quality because of their dense or low canopy (SATMACI 1984; FIRCA 2008). More recently, as part of the Cocoa Swollen Shoot Virus (CSSV) control strategy a new list of trees that should be excluded from cocoa fields is being disseminated to farmers (CNRA 2011), further limiting their options for tree management. Little or no scientific evidence exists as to the compatibility of most of these tree species or their host status for CSSV.

Tree removal has been synonymous with intensification practices linked to superior hybrids and external chemical inputs that result in short term increases in cocoa yield. However, in the longer term, the social and economic value of associated trees in cocoa fields has been shown to contribute to reducing household vulnerability to climatic stress, pest and diseases infestations, cocoa price fluctuations and food insecurity (Tscharntke et al. 2011). Diverse shaded cocoa systems provide a range of products and environmental services, key for the sustainability of cocoa systems and local farmers' livelihoods (Duguma et al. 2001; Bisseleua et al. 2009). Trees on cocoa farms support rural communities by meeting household demand for essential products such as timber, fuel wood and fruits and by enabling the diversification of income sources with high value products that can reduce the risks associated with 
relying solely on cocoa revenues (Herzog 1994; Sonwa et al. 2007, 2014; Cerda et al. 2014). From a conservation point of view, agroforestry systems involving perennial tree crops associated with a diversity of trees can be important systems when replacing tropical forest because they constitute reservoirs of biodiversity (Rice and Greenberg 2000) and hold important carbon storage potential (Somarriba et al. 2013; Saj et al. 2013). Furthermore, research into cocoa agroforestry systems has shown that trees can increase and sustain cocoa system productivity through eco-physiological, economic and environmental interactions (Clough et al. 2009). With the appropriate species and management regimes, the productivity of cocoa farms can be enhanced through amongst others; soil fertility improvement (Isaac et al. 2007), microclimatic amelioration (Tscharntke et al. 2011), reduction in pests and diseases (Schroth et al. 2000; Bos et al. 2007) and increasing resilience to climate change (Duguma et al. 2001; Franzen and Mulder 2007). Linkages between cocoa productivity and vegetation structure are still poorly understood and research on farmers' shade management strategies is important to understand how spatial distribution, tree density and species composition affect productivity (Deheuvels et al. 2012).

Despite the growing evidence that more complex multi-strata shaded cocoa systems can improve livelihood and landscape management, there is still a lack of both fundamental and applied research into cocoa agroforestry systems in West Africa. In Côte d'Ivoire in particular, efforts have focused mainly on the agronomic intensification of high yielding hybrids with a recent interest in leguminous tree species in fallow rehabilitation and cocoa replanting strategies (Asare 2006; Tscharntke et al. 2011). Challenges associated with ageing and maintenance of cocoa farms, as well as questions related to the economic and environmental sustainability of such systems, require the design of new cocoa agroforestry management strategies. Consumers worldwide have fueled an increasing demand for eco-certified cocoa through which farmers receive a premium for cultivating cocoa under a diverse layer of native shade trees and for following more environmentally-friendly practices (Franzen and Mulder 2007). New knowledge is required to understand how to manage more diverse shade systems to restore and enhance ecosystem service provision in the broader landscape. Cocoa fields have mainly been established on forestland and trees now found associated with cocoa are influenced by a combination of factors that include; the native tree cover, farmer preferences, research recommendations and the activities of extension services (Asare 2006). How local people manage natural resources is dependent on their knowledge and on the opportunities, constraints and trade-offs that may exist around integrating trees with cocoa. The aim of this research was to improve our understanding of associated trees in cocoa systems in the South-West of Côte d'Ivoire. The main objective is to increase both productivity and sustainability of cocoa farming in the region of Soubre through improved genetic material and the promotion of good cocoa farming practices. With the aim of exploring opportunities for integrating trees that increase the delivery of ecosystem services on cocoa farms, the specific objectives of our study were to identify trends in tree species diversity in (1) ecocertified and non eco-certified cocoa farms and (2) between farmers of different ethnic origin, to compare perceptions and knowledge about general and specific tree cocoa associations.

\section{Materials and methods}

\section{Study area}

The study area covered four villages and the surrounding 'campements' with different migrant communities in two departments: Gligbaeudji (San Pedro), Kragui, Petit Bouaké and Buyo (Soubré) across the Bas-Sassandra region in the South-West of Côte d'Ivoire. The sites were selected because they represented a diversity of zones covered by the ICRAF/ MARS Vision for Change (V4C) project and due to the presence of eco-certified cooperatives that have been active for at least 3 years. The climate is subequatorial, following a bimodal seasonal regime with two wet seasons, one from March to June and one from September to October. The annual average temperatures range from 24 to $29{ }^{\circ} \mathrm{C}$ and average annual rainfall ranges from 1,600 to $1,800 \mathrm{~mm}$ (Brou 2010). The soils are ferralitic and highly prone to leaching. The natural vegetation of the South-West of Côte d'Ivoire is evergreen forest belonging to the Guinea-Congo Basin massif forest. The main land uses are cocoa, oil palm and rubber. Total population 
of this zone was estimated at over 940.000 inhabitants, with $\sim 74 \%$ living in rural areas. Once a sparsely populated forest area, the population density of the Soubre department is today significantly higher than the national average (48 inhabiant per $\mathrm{km}^{2}$ ), and averaged 76 inhabitant per $\mathrm{km}^{2}$ (ICRAF 2011). This is mainly due to the expansion of the cocoa sector, which attracted both national and foreign migrants. Native population (mainly Bakoué, Bete and Kouzie) constitutes only about $30 \%$ of the total population. National migrants (Baoulé, Agni, Abron, Wan, Sénoufo and Malinké) account for $45 \%$ and foreign migrants, primarily from neighbouring Burkina Faso and Mali, account for $23 \%$ (Assiri et al. 2009).

\section{Data collection}

A structured questionnaire was used to collect data. In the first part of the questionnaire, we collected characterization information about the farmers and their cocoa fields (number and size of fields, mode of acquisition, associated crops and tree species). The second part of the questionnaire contained open-ended questions about the general perceptions of production benefits and drawbacks linked to associated tree species in cocoa fields. A series of specific questions covering tree uses and direct tree cocoa interactions such as physical damage from branches, competition for nutrients and relationship with key cocoa pests and diseases (Phytophtora spp, mirids, rodents, mistletoe) were asked systematically for ten of the tree species present in cocoa fields. If the farmer had more than 10 species present in his fields, the trees evaluated by farmers were randomly selected from the list of trees species present. The majority of cocoa farmers were interviewed in their cocoa fields in order to enable an easier recollection of the trees present and their interactions with cocoa. However in cases where the farms were large or were composed of isolated plots that were not easily reachable, the list of trees was based on farmers' recollection of trees present in the cocoa fields.

Trees were recorded using local vernacular names. A visual aid folder based on the floristic guide of the Tai National Parc (OIPR and GTZ 2000) was used to facilitate the identification of trees with images and local names. A field visit was conducted by one of the authors, Dr. Gnahoua, a forest botanist, for botanical verification of as many unidentified forest tree species as possible. The Floristic Institute of Cocody University provided additional help in species identification. Only tree species that were described by at least 20 farmers are included in the results section.

Sampling strategy

The objective was to survey the persons that make management decisions about their cocoa farms. The sample was stratified according to ethnic origin, participation in eco-certification schemes and location (Table 1). Whether or not farmers were eco-certified (Rainforest Alliance or UTZ) was a second stratification criterion. With respect to location, 90 farmers were interviewed in Kragui, 91 in Petit Bouaké, 90 in Buyo and 85 in Gilgbeaudji. A total of 21 women were included in the sample.

Data analysis

Means and standard deviations for two variables; number of associated tree species and tree density in cocoa fields were computed. Anova analysis was performed with XLSTAT 2013 (Version 4.05) with a comparison of the means according to the NewmanKeuls test at the significance level of $5 \%$ to explore statistical differences between certification status and ethnic origin on the number and density of trees in cocoa fields.

\section{Results}

Characterization of cocoa farms

The area of cocoa in the study area was expanding rapidly from the mid 1970 s to mid 1980 s, almost a quarter $(24.2 \%)$ of cocoa fields in the sample were established in the 1960 s, the vast majority ( $88 \%$ ) were

Table 1 Number of farmers interviewed in the survey in the South-West of Côte d'Ivoire according to ethnic origin and eco-certification status

\begin{tabular}{lccc}
\hline Ethnic origin & Eco-certified & Non eco-certified & Total \\
\hline Local & 59 & 57 & 116 \\
National migrant & 66 & 57 & 123 \\
Foreign migrant & 64 & 52 & 116 \\
Total & 189 & 166 & 355 \\
\hline
\end{tabular}




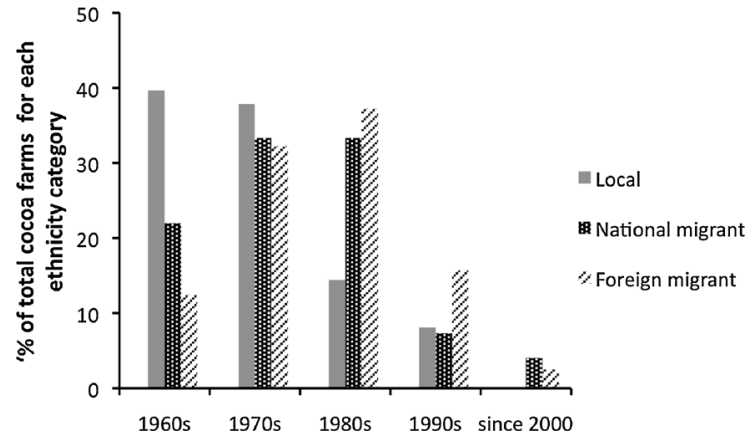

Fig. 1 Proportion of the total number of cocoa fields for each ethnicity category of farmers that were established in each of the last five decades in the South-West of Côte d'Ivoire

over 20 years old with well over half (59\%) being more than 30 years old. There was a decrease in the establishment of new cocoa fields from the mid-1980s, with only $2 \%$ of cocoa fields in the survey having been established after 2000. Whereas most of the local farmers in the survey had established their cocoa fields by the end of the 1970s, many of the national and foreign migrants established their farms in the 1980s (Fig. 1).

Most local farmers had small cocoa fields ( $<5$ ha) compared to national and foreign migrants, who had fields ranging between 2 and 10 ha (Fig. 2). There were no local farmers and very few migrant farmers that had cocoa fields larger than 20 ha. Field size was not significantly affected by farmers' eco-certification status. The majority of farmers cultivated a single cocoa field (76 \%) whilst $19 \%$ had two, $4 \%$ three and $3 \%$ had four separate cocoa fields. In terms of crops associated with cocoa, taro (Colocasia esculenta) was the dominant crop grown (82\%), although farmers said that it was increasingly threatened by the use of herbicides in cocoa fields. Almost a third (30\%) of farmers did not grow any food crops in their cocoa fields, while the majority (70 \%) used empty spaces in the field for growing food crops. These were mainly Musa spp. (on $53 \%$ of farms), yam (Dioscorea rotundata) $(47 \%)$ and cassava (Manihot esculenta) (30\%) but also included vegetables like aubergine (Solanum melongena), chili pepper (Capsicum spp.) and pineapple (Ananas comosus) mainly planted on field boundaries. Ten farmers also intercropped coffee in their cocoa fields.

Tree diversity in cocoa fields

The mean number of tree species found on cocoa plots was highly variable within and between certified and non-certified farmers and ethnic origin categories and hence there were no significant difference amongst them (Table 2). Overall, there were almost ten species per farm (mean of $9.6 \pm 4.6$ ) with more naturally regenerated $(6.0 \pm 3.4)$ than planted tree species $(4.0 \pm 1.8)$.

There was a clear trend of decreasing tree density with increasing field size (Table 3). The highest tree densities were observed in the smallest cocoa fields, especially those $<2$ ha. Although the trend of decreasing tree density with field size was more distinct for eco-certified farms, there was no significant difference in mean tree densities between eco-certified and non eco-certified farmers. Overall, 74 tree species were botanically identified and evaluated by farmers. A further 84 vernacular tree names, in more than six local dialects, were also recorded but their botanical equivalents could not be verified, and 39 farmers, of different ethnic origins, described one or more trees without being able to give them a vernacular name.

Over 50 tree species ( 7 exotic and 44 native) from 27 botanical families were present on at least three cocoa farms and ranked according to their frequency of occurrence on farms (Table 4). The overwhelming majority of tree species in cocoa fields were native and naturally regenerated but the most frequently encountered species were exotic fruit trees planted by farmers and used for nutrition and income. Ten species found on cocoa farms were listed in the IUCN red list of endangered species with different conservation ratings; lower risk/least concern (5), lower risk/near threatened (2), vulnerable (2) and endangered (1).

Farmers' perceptions about tree species grown with cocoa

An overwhelming majority of cocoa farmers (338 out of 355) expressed a generally favorable opinion about integrating trees in their cocoa fields. The most important benefits of trees mentioned by farmers were related to ecosystem services including protection of cocoa trees from heat stress, especially in the dry season, and soil fertility improvement, both mentioned by over half the farmers (Table 5). The value of trees for 'bringing rain', increasing soil moisture availability and controlling soil erosion, was mentioned by over $20 \%$ of farmers. The most important drawbacks of trees in cocoa plots were that they could cause physical damage to cocoa, mentioned by almost a third of 

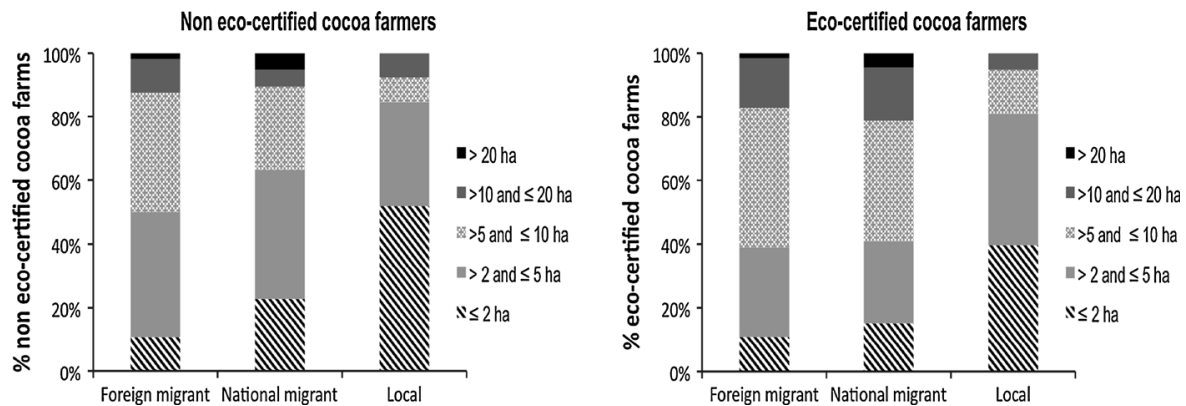

Fig. 2 Percentages of eco-certified and non eco-certified cocoa farms in different size categories according to ethnic origin of farmers in the South-West of Côte d'Ivoire

Table 2 Means and standard deviations of numbers of tree species (planted and naturally regenerated) in cocoa fields, according to ecocertification status and ethnic origin in the SouthWest of Côte d'Ivoire

No significant differences $(p<0.05)$ were observed between means within the same column

\begin{tabular}{lrll}
\hline Type of farmer & $\begin{array}{l}\text { Total number } \\
\text { of tree species }\end{array}$ & $\begin{array}{l}\text { Number of naturally } \\
\text { regenerating species }\end{array}$ & $\begin{array}{l}\text { Number of } \\
\text { planted species }\end{array}$ \\
\hline Eco-certified & $10.0 \pm 4.6$ & $5.8 \pm 3.3$ & $4.2 \pm 1.9$ \\
Local & $9.6 \pm 4.9$ & $5.9 \pm 3.5$ & $3.7 \pm 1.7$ \\
National migrant & $10.3 \pm 4.6$ & $6.1 \pm 3.3$ & $4.2 \pm 1.9$ \\
Foreign migrant & $10.0 \pm 4.4$ & $5.5 \pm 3.1$ & $4.6 \pm 2.0$ \\
Non eco-certified & $9.2 \pm 4.6$ & $5.3 \pm 3.6$ & $3.9 \pm 1.6$ \\
Local & $8.3 \pm 4.6$ & $5.0 \pm 3.6$ & $3.3 \pm 1.7$ \\
National migrant & $10.1 \pm 4.7$ & $5.8 \pm 3.6$ & $4.3 \pm 1.5$ \\
Foreign migrant & $9.0 \pm 4.4$ & $5.0 \pm 3.6$ & $4.0 \pm 1.5$ \\
Grand Average & $9.6 \pm 4.6$ & $6.0 \pm 3.4$ & $4.0 \pm 1.8$ \\
\hline
\end{tabular}

providing high quality shade and soil fertilization while drawbacks were related to attracting pests and diseases and competition for nutrients and water (Table 6).

Some tree species were clearly identified as negative for specific issues such as attracting small rodents, competing for nutrients and hosting parasitic plants (Fig. 4).

For example, Elaeis guineensis was perceived by $82 \%$ of farmers as attracting rodents, Psidium guaj$a v a$ by $100 \%$ of farmers for nutrient competition and Cola nitida by $76 \%$ of farmers for being an alternative host for parasitical plants (Tapinanthus spp.). On the other hand, very few trees were perceived as a threat in terms of doing physical damage from branches falling on cocoa. The two trees most associated with physical damage were Ceiba pentandra and Triplochiton scleroxylon mentioned by almost two-thirds of farmers (62 and $60 \%$, respectively). Farmers did not perceive the large majority of tree species grown with cocoa as attracting mirids (Sahlbergella sp. and Distantiella sp.). Trees commonly identified as hosts of mirids were $C$. nitida and $M$. indica with 38 and 
Table 3 Mean values and standard deviations of tree density in cocoa fields based on interviews with farmers according to ecocertification status, ethnic origin and size of cocoa field in the South-West of Côte d'Ivoire

\begin{tabular}{lccccc}
\hline Farm size type of farmer & $\leq 2$ ha & $>2$ and $\leq 5$ ha & $>5$ and $\leq 10$ ha & $>10$ and $\leq 20$ ha & $>20$ ha \\
\hline Eco-certified & $14.8 \pm 12.3 \mathrm{a}$ & $8.8 \pm 6.7 \mathrm{~b}$ & $5.9 \pm 4.8 \mathrm{c}$ & $4.0 \pm 2.4 \mathrm{c}$ & $3.1 \pm 2.1 \mathrm{c}$ \\
Local & $14.0 \pm 12.2 \mathrm{a}$ & $7.6 \pm 4.5 \mathrm{~b}$ & $3.9 \pm 1.6 \mathrm{c}$ & $2.6 \pm 1.5 \mathrm{c}$ & - \\
National migrant & $21.0 \pm 13.2 \mathrm{a}$ & $10.6 \pm 10.0 \mathrm{ab}$ & $6.7 \pm 5.6 \mathrm{~b}$ & $4.4 \pm 2.7 \mathrm{~b}$ & $3.5 \pm 2.4 \mathrm{~b}$ \\
Foreign migrant & $8.2 \pm 5.0 \mathrm{a}$ & $8.7 \pm 4.6 \mathrm{a}$ & $5.8 \pm 4.5 \mathrm{ab}$ & $3.9 \pm 2.1 \mathrm{~b}$ & $2.1 \pm 0.0 \mathrm{~b}$ \\
Non eco-certified & $17.1 \pm 17.5 \mathrm{a}$ & $8.1 \pm 5.9 \mathrm{ab}$ & $4.7 \pm 4.1 \mathrm{ab}$ & $2.2 \pm 1.7 \mathrm{~b}$ & $4.6 \pm 2.5 \mathrm{ab}$ \\
Local & $14.9 \pm 15.7 \mathrm{a}$ & $5.4 \pm 2.8 \mathrm{~b}$ & $4.8 \pm 3.2 \mathrm{~b}$ & $1.6 \pm 0.8 \mathrm{c}$ & - \\
National migrant & $20.4 \pm 21.7 \mathrm{a}$ & $10.4 \pm 7.3 \mathrm{ab}$ & $5.2 \pm 4.7 \mathrm{~b}$ & $3.8 \pm 2.6 \mathrm{~b}$ & $4.4 \pm 2.8 \mathrm{~b}$ \\
Foreign migrant & $19.7 \pm 13.3 \mathrm{a}$ & $7.9 \pm 5.2 \mathrm{ab}$ & $4.4 \pm 3.7 \mathrm{~b}$ & $1.8 \pm 0.9 \mathrm{c}$ & $5.3 \pm 0.0 \mathrm{~b}$ \\
Grand average & $16.0 \pm 15.4$ & $8.5 \pm 6.3$ & $5.4 \pm 4.6$ & $3.4 \pm 2.3$ & $3.9 \pm 2.4$ \\
\hline
\end{tabular}

Mean values with the same letter within the same row are not significantly different $(p<0.05)$

$30 \%$, respectively. Similarly, most trees were not perceived by farmers as causing the spread of black pod disease (Phytophtora spp.) with only C. nitida frequently being reported by $38 \%$ of farmers.

Access to advice on integrating trees in cocoa fields

Among the 189 eco-certified farmers interviewed, 150 farmers were affiliated to cooperatives engaged in the Rainforest Alliance eco-certification scheme and 46 were engaged in eco-certification with UTZ Certified in the Buyo area. There was a large difference between the numbers of eco-certified farmers $(76.1 \%)$ and non eco-certified farmers $(15.7 \%)$ that had received advice on growing trees in cocoa fields. Advice focused on the benefits of trees for soil fertility improvements and general benefits of shade (Table 7).

Cocoa farmers' knowledge of tree density required for eco-certification varied from 7 to 70 trees $\mathrm{ha}^{-1}$ (Table 8) with half of the farmers mentioning 18 trees $\mathrm{ha}^{-1}$. Almost a third of eco-certified farmers were unaware of the number of trees required. Farmers' knowledge of the number of different tree species required for eco-certification also varied widely (from 1 to 18) with almost a third of farmers opting for three or less and almost half of the eco-certified farmers simply stating that they did not know the number of species required.

Only a small proportion of eco-certified farmers had received advice about specific tree species to grow with cocoa, with Terminalia spp. overwhelmingly promoted (Table 9).
Overall, farmers expressed the desire to plant 52 different tree species in their cocoa fields. Amongst the twenty species most desired (Table 10), almost a third of farmers had a preference for five species that included native shade trees (Terminalia spp., Ricinodendron heudelotii, Ceiba pentandra) and two exotic fruit trees ( $P$. americana and $C$. sinensis). There was no difference in preferences between ethnic categories except for $C$. nitida which was favored by foreign migrants. Terminalia superba was the tree most desired by eco-certified farmers when compared to non eco-certified farmers.

\section{Discussion}

Characterization of cocoa farms

The times of establishment of cocoa plots by farmers of different ethnicity to the East to West progression of the cocoa pioneer front in the 1970s and 1980s, with an increasing number of migrants benefiting from soil fertility built up under forest, opportunities arising from the bridge constructed over the Sassandra river and a policy environment in the country that favored cocoa cultivation (Léonard and Ibo 1994). The majority of cocoa fields in the project area were between 20 and 30 years old. A recent survey of cocoa farms showed that over $50 \%$ of cocoa farmers in the Soubré region have been using unselected material, only $8 \%$ using Amelonado varieties, and the average yield quoted for the region was $560 \mathrm{~kg} / \mathrm{ha}$ without any information on variability provided (Assiri et al. 


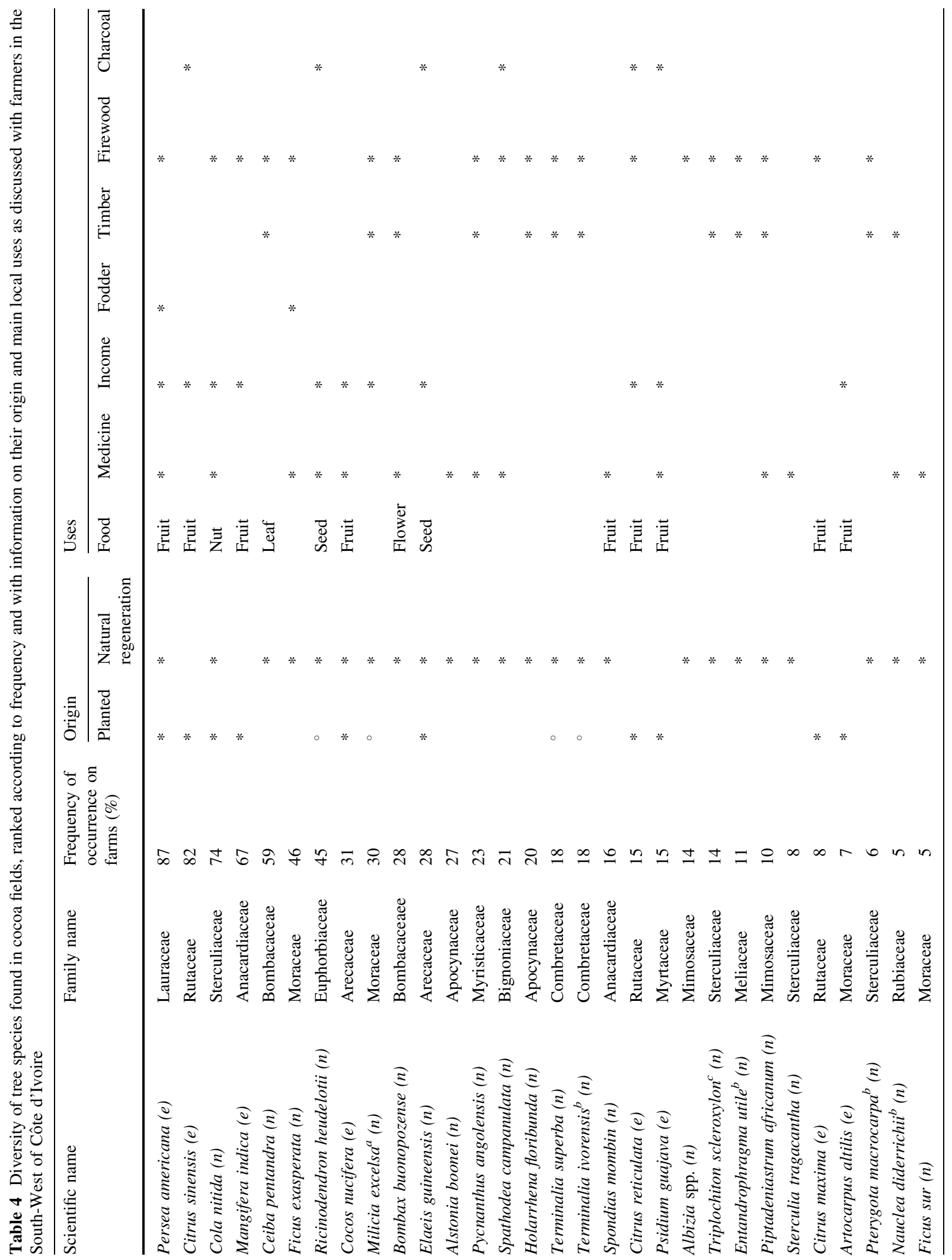




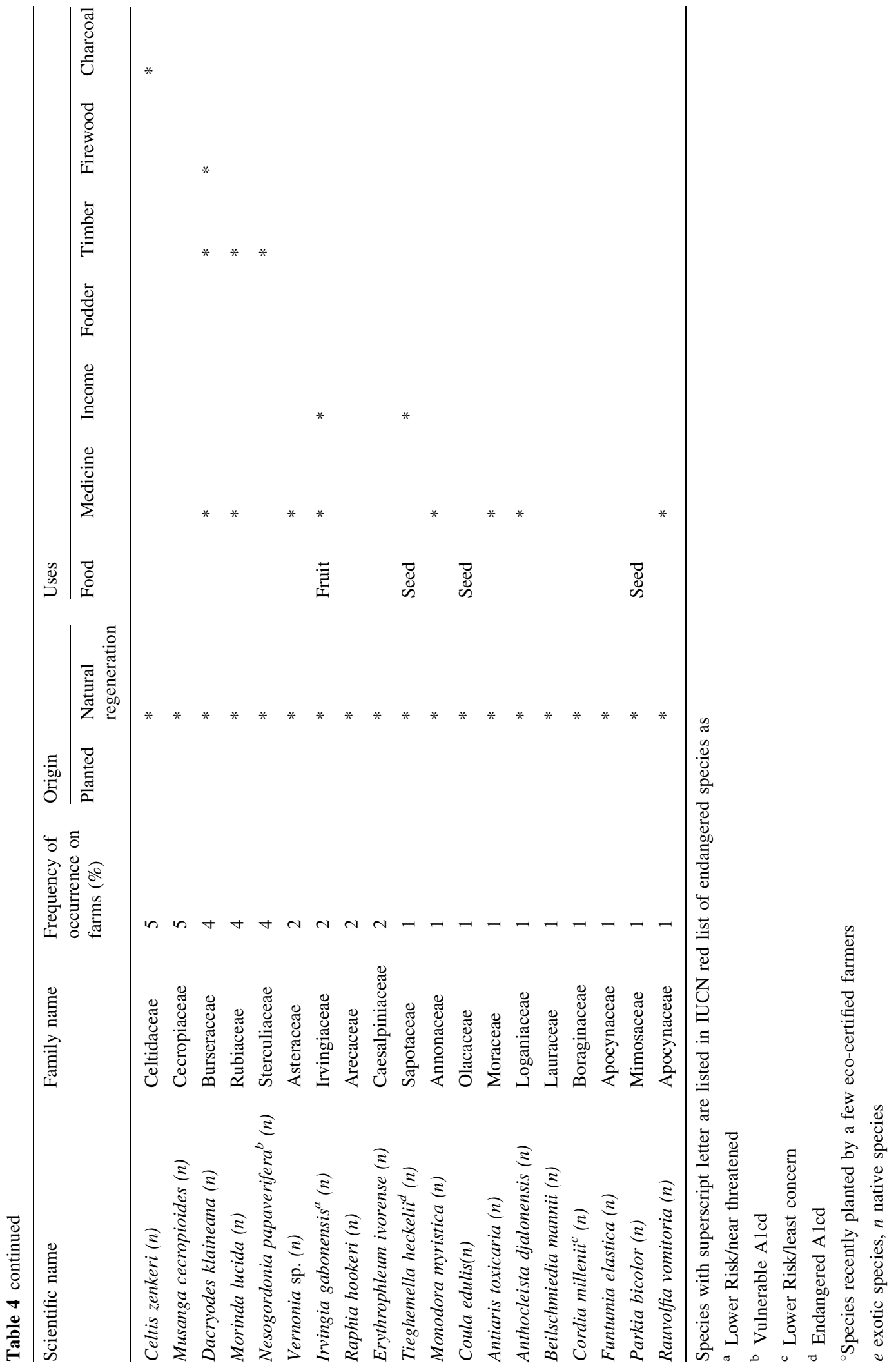


Table 5 Main production benefits and drawbacks of integrating trees with cocoa reported by eco-certified and non eco-certified farmers in the South-West of Côte d'Ivoire

\begin{tabular}{|c|c|c|c|c|c|c|c|}
\hline Benefits & $\begin{array}{l}\text { Total } \\
\text { farmers } \\
(\%)\end{array}$ & $\begin{array}{l}\text { Eco- } \\
\text { certified } \\
(\%)\end{array}$ & $\begin{array}{l}\text { Non eco- } \\
\text { certified } \\
(\%)\end{array}$ & Drawbacks & $\begin{array}{l}\text { Total } \\
\text { farmers } \\
(\%)\end{array}$ & $\begin{array}{l}\text { Eco- } \\
\text { certified } \\
(\%)\end{array}$ & $\begin{array}{l}\text { Non eco- } \\
\text { certified } \\
(\%)\end{array}$ \\
\hline $\begin{array}{l}\text { Protect cocoa } \\
\text { against heat stress }\end{array}$ & 70.1 & 72.3 & 68.7 & Physical damage & 32.7 & 34.6 & 30.7 \\
\hline Increase soil fertility & 52.7 & 57.4 & 47.6 & Rodents increase & 23.9 & 26.1 & 21.7 \\
\hline 'Bring rain' & 28.2 & 30.3 & 25.9 & Nutrient competition & 6.8 & 7.4 & 6.0 \\
\hline Increase soil moisture & 23.7 & 25.5 & 21.7 & Pod rot increase & 6.8 & 8.5 & 4.8 \\
\hline Control erosion & 21.7 & 26.6 & 24.1 & Shading decreases yield & 4.5 & 3.2 & 6.0 \\
\hline Increase cocoa production & 9.9 & 9.6 & 10.2 & Increase parasitic plant & 3.7 & 2.7 & 4.8 \\
\hline Protect cocoa from wind & 5.1 & 3.7 & 6.6 & Excessive humidity & 3.1 & 5.3 & 0.6 \\
\hline No benefits & 4 & 4 & 5 & Mortality of neighbouring cocoa & 2.8 & 3.2 & 2.4 \\
\hline $\begin{array}{l}\text { Provide shade for } \\
\text { farmer to rest under }\end{array}$ & 3.7 & 2.7 & 4.8 & No problems identified & 2.5 & 1.1 & 4.2 \\
\hline $\begin{array}{l}\text { Increase cocoa resistance } \\
\text { pests and diseases }\end{array}$ & 2.0 & 1.6 & 2.4 & Decrease in yields & 2.5 & 2.1 & 3.0 \\
\hline No answer provided & 0 & 0 & 0 & No answer provided & 43 & 43.1 & 42.2 \\
\hline
\end{tabular}

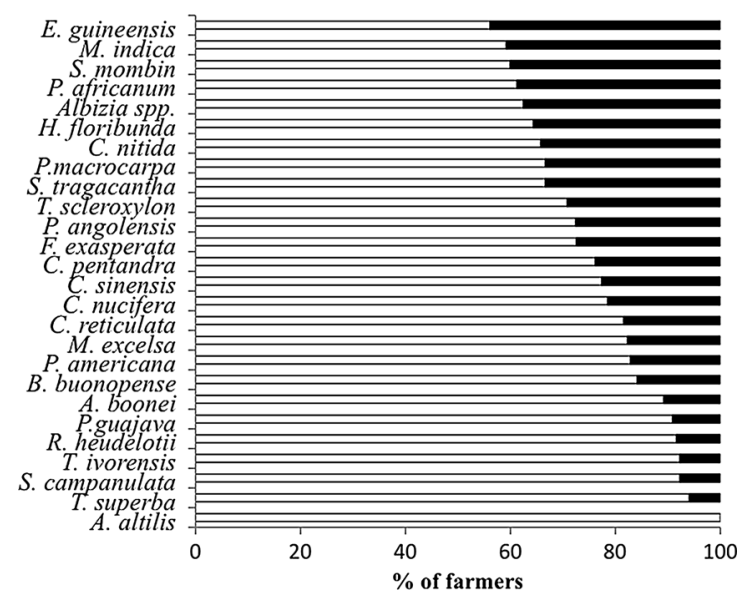

Fig. 3 General compatibility of tree species associated with cocoa as perceived by farmers in the South-West of Côte d'Ivoire (white square box: compatible; black square box: incompatible)

2009). Research in Ghana has shown that the economic lifespan of intensively managed hybrid cocoa ranges from around 18 to 29 years (Obiri et al. 2007), indicating that much of the cocoa in the study area is nearing the end of its productive life. In contrast, a recent study has shown that by constantly eliminating low yielding, damaged or diseased trees, farmers in complex cocoa agroforestry systems in Cameroon can extend the productive life of their plantation up to over 40 years (Jagoret et al. 2011, 2014). The reduction in number of new cocoa farms established since 1985 coincides with forestland becoming scarce at the same time as world cocoa prices were declining (Ruf and Zadi 1998). The farm size distribution confirms that cocoa has remained a predominantly smallholder enterprise in the country, with most farms $<10$ ha and almost a quarter $<2$ ha. In general, local farmers had smaller plots than migrant farmers who generally acquired larger areas to make the migration worthwhile.

Tree diversity in cocoa fields

Farmers described a rich diversity of tree species on their cocoa farms, including 74 species that could be botanically identified, 63 of which were native. A further 84 vernacular tree names in six different dialects were recorded, but were not botanically identified and hence may contain some overlap amongst themselves and with the 74 identified species. Consequently, the likelihood is that farmers recognized well over 100 different species that were growing in their cocoa fields. The difficulty and limitations of identifying species from vernacular names, inherent in ethno-botany (Wilkie and Saridan 1999), was further complicated in the present context by the linguistic diversity in the survey area, and, by the sparse knowledge about native flora 
Table 6 Summary of farmers' perceptions of key benefits and drawbacks associated with the five most compatible and the five least compatible tree species grown with cocoa in the South-West of Côte d'Ivoire

\begin{tabular}{|c|c|c|}
\hline Tree name & Benefits & Drawbacks \\
\hline $\begin{array}{l}\text { Terminalia } \\
\text { superba }\end{array}$ & $\begin{array}{l}\text { Good shade quality, increases soil moisture, soil fertility } \\
\text { improvement, timber }\end{array}$ & Attracts rodents, unclear timber value, \\
\hline $\begin{array}{c}\text { Terminalia } \\
\text { ivorensis }\end{array}$ & Good shade quality, soil fertility improvement, timber & Attracts rodents, unclear timber value \\
\hline $\begin{array}{l}\text { Ricinodendron } \\
\text { heudelotii }\end{array}$ & $\begin{array}{l}\text { Nutrition, income and cultural value, increases soil } \\
\text { humidity, good shade quality, soil fertility improvement }\end{array}$ & Attracts rodents \\
\hline $\begin{array}{l}\text { Spathodea } \\
\text { campanulata }\end{array}$ & $\begin{array}{l}\text { Increases soil moisture, soil fertility improvement because } \\
\text { of fast decomposing litter }\end{array}$ & Attracts rodents and mistletoe \\
\hline Albizia spp. & Good firewood species & $\begin{array}{l}\text { Competitive for nutrients and water, attracts } \\
\text { rodents, causes physical damage }\end{array}$ \\
\hline $\begin{array}{l}\text { Piptadeniastrum } \\
\text { africanum }\end{array}$ & Timber & $\begin{array}{l}\text { Competitive for nutrients and water, physical } \\
\text { damage, attracts rodents, negative shade }\end{array}$ \\
\hline $\begin{array}{l}\text { Spondias } \\
\text { mombin }\end{array}$ & Soil fertility improvement and good shade quality & Attracts mistletoe and rodents, few uses \\
\hline Mangifera indica & Nutrition, income & $\begin{array}{l}\text { Competitive for nutrients, dense shade, attracts } \\
\text { mirids and rodents }\end{array}$ \\
\hline Eleais guineensis & Nutrition, cultural value, income & $\begin{array}{l}\text { Low quality shade and cumbersome crown, attracts } \\
\text { rodents, competitive for water and nutrients }\end{array}$ \\
\hline
\end{tabular}

amongst some migrant farmers, recently arrived from very different agroecological conditions in their home regions. This is an important result that underlines the challenges of communicating and sharing knowledge about trees associated with cocoa amongst farmers, extension workers and scientists. The tree species richness found on cocoa farms in the study area was significantly higher than those shown by previous inventories in the central region of Côte d'Ivoire, where 25 tree species were recorded (Herzog 1994). The results were also higher than those shown by a study in the Ondo State in Nigeria, with 45 species (Oke and Odebiyi 2007) and by an inventory of mature cocoa farms in the Ashanti region of Ghana that recorded 66 species (Anglaaere et al. 2011). On the other hand, it was lower than the richness described in studies of traditional agroforestry systems in Cameroon where 206 tree species were inventoried (Sonwa et al. 2007) and cocoa agroforests in central Cameroon where 165 tree species were inventoried (Nomo et al. 2008). The survey results indicate that, despite the significant deforestation trends and the promotion of full-sun cocoa, the cocoa farms in the South-West of Côte d'Ivoire represent a refuge for a large number of native tree species. These include ten species on the IUCN red list of threatened species conservation status that include one endangered, five vulnerable, two near threatened and two at lower risks.
More information on the abundance of these rare species would be required to assess the extent to which cocoa farms represent effective refugia.

While the diversity of native tree richness interests conservationists, the most frequent tree species were exotic fruit trees used for nutrition and income that had been planted by farmers. This trend is common across other Western and Central African regions where many farmers manage trees in cocoa plantations for the nutritional benefit they provide to the household as well as a range of other productive and service roles (Herzog 1994; Leakey and Tchoundjeu 2001; Asare 2005; Koko et al. 2013; Sonwa et al. 2014). Sixty percent of Ivorian farmers in the Bas-Sassandra region planted fruit trees in their cocoa plots, a situation slightly above the Ivorian average but similar to cocoa farms studies in Ghana and Nigeria (Gockowski et al. 2004). Cocoa fields appeared to be the only significant farm niche where fruit trees were planted and managed by farmers in the study area. Homesteads were generally kept free of trees because the land was used primarily for cocoa drying. Fallows were rare, cropland scare and trees rarely associated with other local land uses such as food crops, paddies, rubber or oil palm. There were no significant differences between farmers of different ethnic origin, eco-certification status or the age of their plantations, in terms of the 
(a) causes physical damage

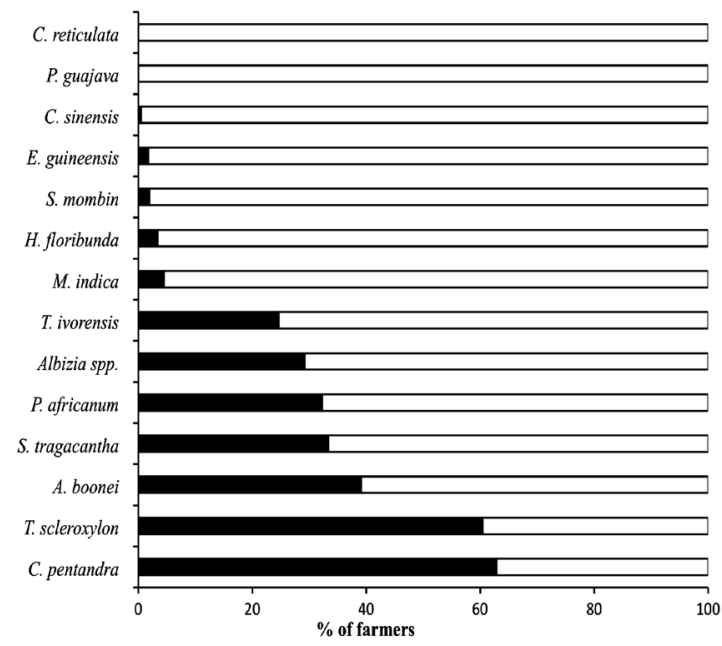

(C) competitiveness for nutrients

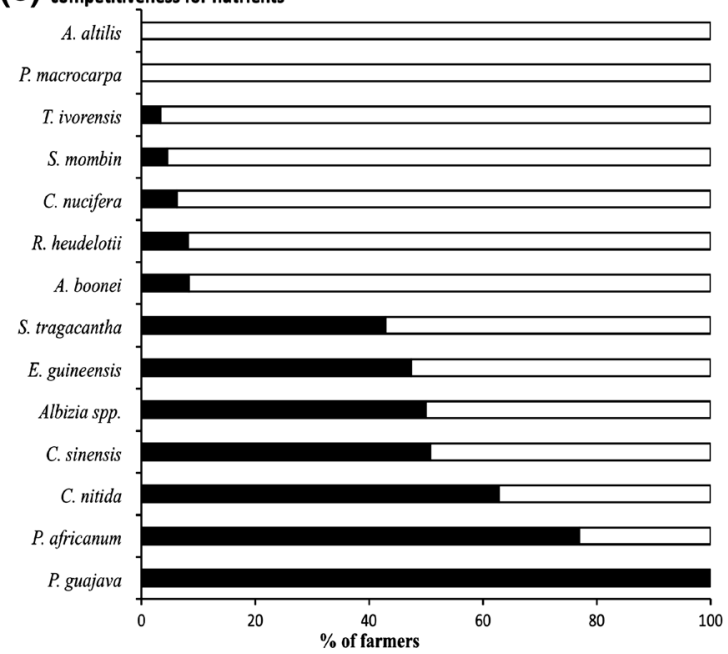

(e) alternative host of mirids

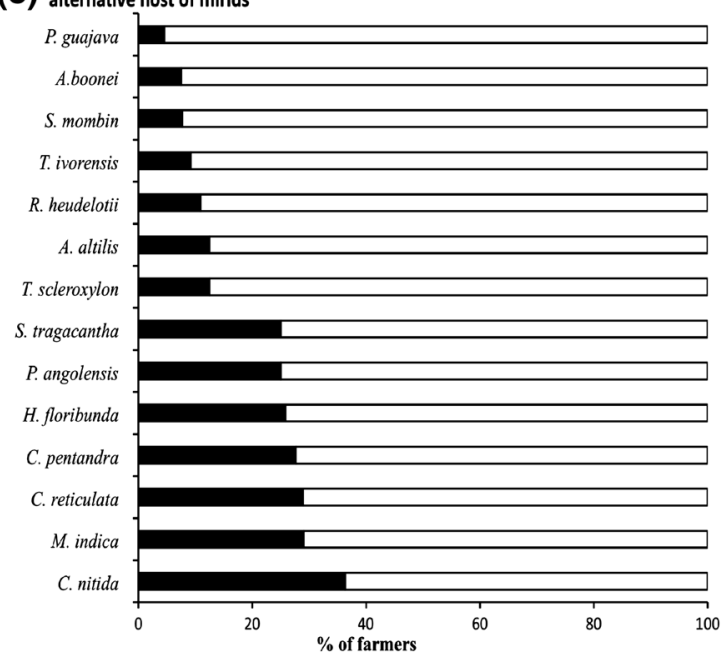

(b) attracts rodents

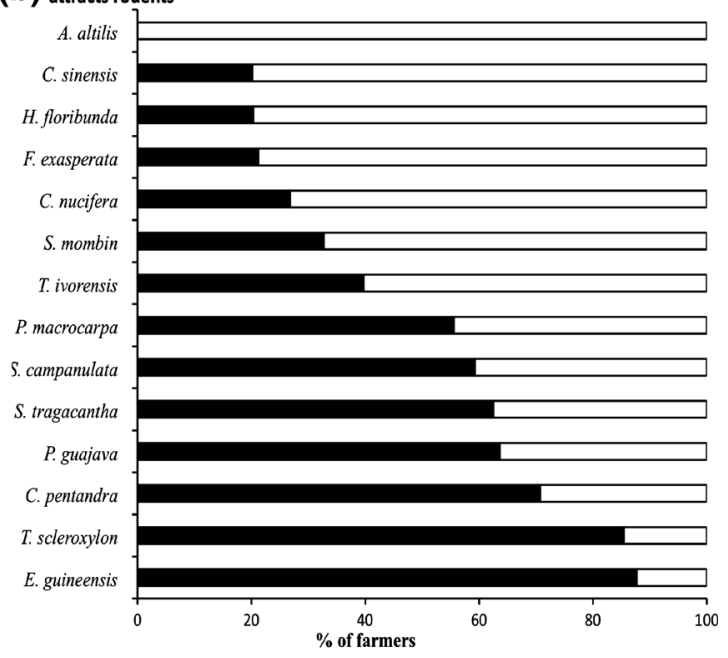

(d) favouring Phytophtora spp

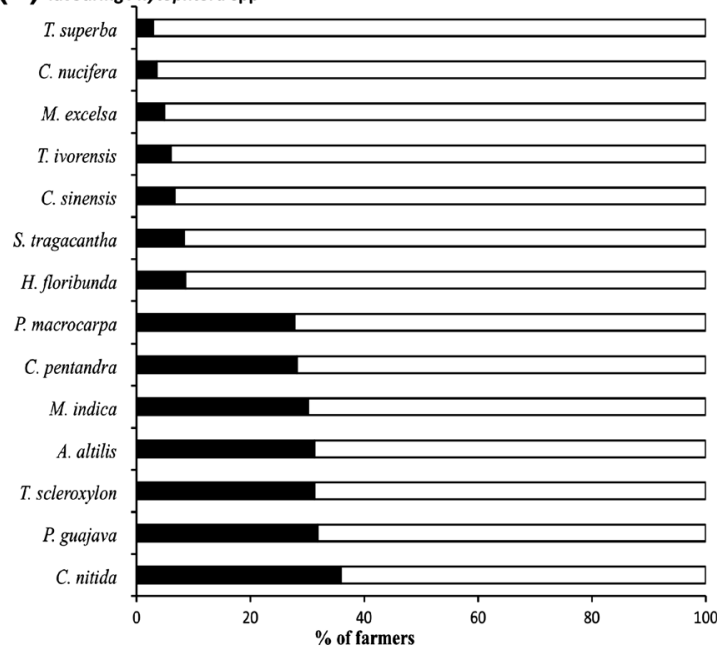

(f) alternative host of miseltoe

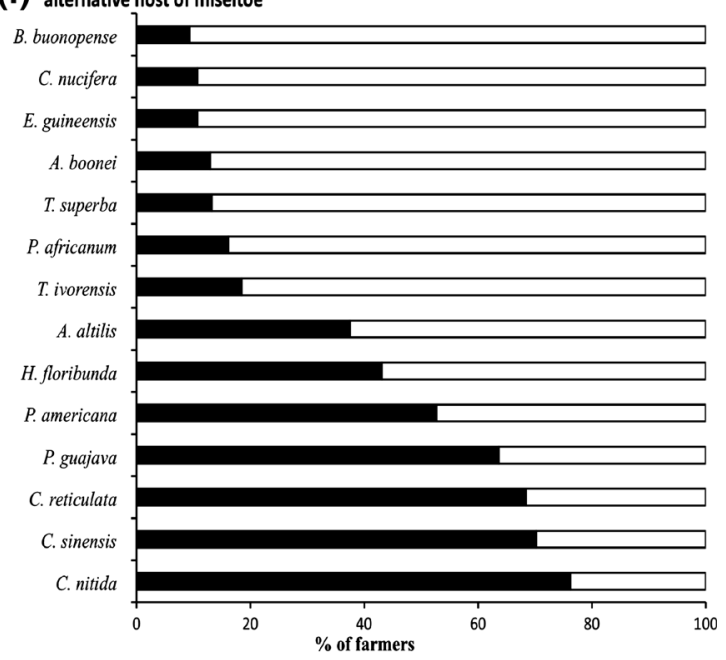


4 Fig. 4 Status of tree species associated with cocoa perceived by farmers in the South-West of Côte d'Ivoire with respect to: a Physical damage by branches, b attractiveness to rodents, c competitiveness for nutrients, d favouring Phytophtora spp., e alternative host of mirids, and $\mathbf{f}$ alternative host of mistletoe (Tapinanthus spp). Data shown only for the seven most and seven least susceptible species (white square box: no; black square box: yes)

Table 7 Number of farmers who have received different types of advice about shade tree associations in cocoa fields according to eco-certification status in the South-West of Côte d'Ivoire

\begin{tabular}{lll}
\hline Nature of advice & $\begin{array}{l}\text { Eco- } \\
\text { certified }\end{array}$ & $\begin{array}{l}\text { Non eco- } \\
\text { certified }\end{array}$ \\
\hline Soil fertility improvement & 50 & 2 \\
Shade is beneficial & 45 & 3 \\
Specific trees recommended & 45 & 2 \\
Increase cocoa productivity & 17 & 1 \\
Soil moisture retention & 12 & 2 \\
\hline
\end{tabular}

Table 8 Number of eco-certified and non-eco-certified farmers in the South-West of Côte d'Ivoire who stated that they had received advice on planting tree species in their cocoa fields

\begin{tabular}{lllr}
\hline Scientific name & $\begin{array}{l}\text { Eco- } \\
\text { certified }\end{array}$ & $\begin{array}{l}\text { Non eco- } \\
\text { certified }\end{array}$ & Total \\
\hline Terminalia superba & 38 & 0 & 38 \\
Terminalia ivorensis & 17 & 0 & 17 \\
Gliricidia sepium & 4 & 1 & 5 \\
Ricinodendron heudelotii & 4 & 1 & 5 \\
Spondias mombin & 3 & 0 & 3 \\
Milicia excelsa & 0 & 2 & 2 \\
Entandrophragma utile & 1 & 0 & 1 \\
Ceiba pentandra & 0 & 1 & 1 \\
Total & 67 & 5 & 72 \\
\hline
\end{tabular}

number of species found on cocoa plots but the variation was large within each of these categories as found in other studies in Cameroon (Nomo et al. 2008). The mean number of species found per plot was 9.6 with a higher proportion of native naturally regenerating species (6) than of planted species (4) which is higher than the 5.4 species previously recorded in Côte d'Ivoire (Herzog 1994) but lower than farms studied in Central Cameroon where means of 21 tree species ha ${ }^{-1}$ (Sonwa et al. 2007) and 25 tree species ha ${ }^{-1}$ were recorded (Jagoret et al. 2011).
Similar to previous results reported by N'Goran (1998), there was a significant variability in the densities of non-cocoa trees in cocoa fields, although our study did not show density consistently varying with age of the field. In the research area, tree density ranged from 2 to 21 trees ha ${ }^{-1}$ much lower than those recorded in cocoa agroforestry systems in Cameroon which averaged around 120 trees ha $^{-1}$ (Jagoret et al. 2011). Low tree densities are explained partly by the historical promotion of full-sun cocoa systems but are also by the fact that migrant cocoa farmers secure land ownership through the conversion of forest land to agricultural use (Ruf and Zadi 1998; Asare 2005). Densities varied according to the field size, with small fields having the highest densities and a clear decreasing trend in tree density as field size increased. This is consistent with cocoa fields being almost the only farm niche where trees are grown and managed for the household. Farmers with smaller land sizes would intercrop trees more densely in order to meet their needs. The present results were based on farmers' recall and it is possible that there could be systematic bias of recall with farm size. There was no significant difference in tree density between certified and noncertified farmers because most certified farmers had only recently engaged in eco-certification schemes at the time of the survey and had not taken steps to align with the shade tree requirements of between 12 to 18 trees $\mathrm{ha}^{-1}$ and the long term goal of providing $40 \%$ shade cover (SAN (Sustainable Agricultural Network) 2009).

\section{Perceptions about integrating trees in cocoa fields}

The prevailing view within the cocoa industry is that cocoa farmers in Ghana and Côte d'Ivoire will progressively reduce and ultimately eliminate shade in their cocoa fields and, in keeping with this, full sun cocoa is the industry standard (Ruf 2011). In Western Ghana, $90 \%$ of farmers were reported to be eliminating trees to reduce shade, largely as a result of their perception that new cocoa hybrids were intolerant of shade (Ruf et al. 2006). In marked contrast to this, we found that $95 \%$ of farmers in the Western part of Côte d'Ivoire valued the presence of trees associated with cocoa for both products and environmental services, regardless of their origin or certification status. Most of the cocoa in the Western part of Côte d'Ivoire is not of hybrid origin (Gockowski and Sonwa 2011) and this 
could explain why farmers have a positive attitude towards integrating trees with cocoa. The most frequently planted trees in cocoa fields in Western

Table 9 Cocoa farmers' knowledge about the number of trees and species per hectare required for eco-certification in the South-West of Côte d'Ivoire

\begin{tabular}{llll}
\hline $\begin{array}{l}\text { Number } \\
\text { of trees/ha }\end{array}$ & $\begin{array}{l}\text { Eco- } \\
\text { certified } \\
\text { farmers }(\%)\end{array}$ & $\begin{array}{l}\text { Number of } \\
\text { species/ha }\end{array}$ & $\begin{array}{l}\text { Eco- } \\
\text { certified } \\
\text { farmers }(\%)\end{array}$ \\
\hline 70 & 2.1 & 18 & 0.5 \\
25 & 2.6 & 15 & 0.5 \\
20 & 6.3 & 12 & 2.1 \\
18 & 50.8 & 10 & 1.1 \\
15 & 1.1 & 7 & 3.2 \\
12 & 2.1 & 6 & 0.5 \\
10 & 1.1 & 4 & 2.6 \\
7 & 3.7 & 3 & 9.5 \\
Does not know & 31.7 & 2 & 18.5 \\
& & 1 & 12.2 \\
& & Does not know & 48.7 \\
\hline
\end{tabular}

Côte d'Ivoire reported here were fruit trees, used for both household nutrition and income. In addition to products derived from trees, farmers also expressed the importance of the environmental services that they provide. The major environmental benefit perceived by $70 \%$ of farmers was to protect cocoa trees from heat stress in the dry season. Over the last 20 years, there has been increasing report of climate change in southern Côte d'Ivoire, with trends towards reduced rainfall and increased length of the dry season (Brou 2010). Farmers said that drier climatic conditions were the major driver for wanting shade in their fields, especially to protect cocoa trees from water stress in the dry months of January and February. This corroborates the view that changing climatic conditions, with an increase in the length of the dry season, is increasingly affecting cocoa productivity, and requires the design of new strategies, using shade trees to buffer cocoa from water and heat stress in the dry season (N'Goran 1998). Soil fertility improvement was the second most frequently mentioned benefit of incorporating trees in cocoa fields, expressed by more than

Table 10 Percentages of farmers who desired different tree species for cocoa association according to ethnic origin and ecocertification status in the South-West of Côte d'Ivoire (data shown for the twenty trees most desired)

\begin{tabular}{|c|c|c|c|c|c|c|}
\hline Tree species & $\begin{array}{l}\text { National } \\
\text { migrants }(\%)\end{array}$ & $\begin{array}{l}\text { Foreign } \\
\text { migrants }(\%)\end{array}$ & $\begin{array}{l}\text { Local } \\
(\%)\end{array}$ & $\begin{array}{l}\text { Eco-certified } \\
(\%)\end{array}$ & $\begin{array}{l}\text { Non eco- } \\
\text { certified }(\%)\end{array}$ & $\begin{array}{l}\text { Number of } \\
\text { farmers }\end{array}$ \\
\hline Terminalia superba & 50 & 32 & 38 & 52 & 27 & 143 \\
\hline Ricinodendron heudelotii & 46 & 32 & 35 & 39 & 37 & 134 \\
\hline Persea americana & 40 & 43 & 28 & 38 & 36 & 131 \\
\hline Citrus sinensis & 33 & 41 & 27 & 32 & 36 & 119 \\
\hline Ceiba pentandra & 40 & 38 & 19 & 37 & 27 & 115 \\
\hline Terminalia ivoriensis & 36 & 26 & 28 & 35 & 23 & 106 \\
\hline Milicia excelsa & 28 & 16 & 17 & 22 & 19 & 73 \\
\hline Mangifera indica & 20 & 22 & 19 & 19 & 21 & 71 \\
\hline Cola nitida & 15 & 30 & 13 & 15 & 23 & 68 \\
\hline Gliricidia sepium & 0 & 19 & 9 & 20 & 10 & 54 \\
\hline Bombax buonopozense & 15 & 16 & 3 & 13 & 10 & 41 \\
\hline Ficus exasperata & 11 & 9 & 6 & 9 & 9 & 32 \\
\hline Cocos nucifera & 8 & 12 & 5 & 10 & 7 & 30 \\
\hline Alstonia boonei & 8 & 10 & 3 & 11 & 3 & 26 \\
\hline Citrus reticulata & 6 & 3 & 10 & 4 & 9 & 23 \\
\hline Spondias mombin & 9 & 7 & 3 & 10 & 3 & 23 \\
\hline Spathodea campunalata & 12 & 2 & 4 & 6 & 7 & 22 \\
\hline Triplochiton scleroxylon & 6 & 4 & 9 & 6 & 7 & 22 \\
\hline Entandrophragma utile & 6 & 3 & 3 & 4 & 5 & 15 \\
\hline Eleais guineensis & 4 & 3 & 4 & 5 & 2 & 14 \\
\hline
\end{tabular}


$50 \%$ of farmers. The soil conditions prevailing in Soubré make cocoa fields particularly prone to early senescence with attendant low yield and even cocoa mortality (Ruf and Zadi 1998; Koko et al. 2009). Replanting has become increasingly difficult on land not recently cleared from forest (Ruf and Konan 2001). In the absence of new forestland to clear, there is an increasing reliance on the use of chemical fertilizers to maintain yield, which many farmers cannot afford (Assiri et al. 2009). While exotic leguminous trees have recently been promoted in the context of soil fertility improvement, notably in the regional Sustainable Tree Crops Program (Asare 2005), there is little information on the suitability of different tree species to improve both nutrient cycling and soil fertility in different contexts. Trees associated with cocoa systems have been shown to be important for improving soil quality and provide a high level of soil-related ecological services (Rousseau et al. 2012). Research on tree phenology, leaf decomposition rates and $\mathrm{N}$-mineralization from litter of a broad range of tree species, is required to develop guidelines for farmers on which species to use to improve soil health (Barrios et al. 2012). Soil moisture conservation and erosion control were also important services that farmers associated with trees. Only a few farmers linked shade trees with prolonging the life span of cocoa, although this has been frequently observed by scientists (Ruf and Zadi 1998; Obiri et al. 2007). Farmers also did not mention weed suppression as a benefit derived from trees, and this could be due, even with full sun cocoa, to the fact that cocoa density is high and hence shade from the cocoa itself is sufficient to suppress weeds (Assiri et al. 2009).

Farmers mentioned drawbacks of integrating trees with cocoa much less frequently than benefits. The most frequently cited drawback mentioned by about a third of farmers, was physical damage to cocoa or people caused by falling branches, but this was only a drawback with seven species (discussed further below). The second most frequent drawback, mentioned by more than a quarter of the farmers, was attracting rodents and fewer than $10 \%$ mentioned other drawbacks, including favoring an increase in incidence of black pod disease and competition for nutrients. This is broadly consistent with a recent study of cocoa farmer perceptions in Ghana that reported negative ecological interactions, principally attracting squirrels and increasing incidence of black pod disease, as the reason for almost a quarter of farmers (23\%) removing shade trees from their cocoa fields (Ruf 2011). The incidence of black pod disease was linked to high humidity, especially in areas of heavy rainfall. The lack of tree ownership by farmers and destructive practices associated with timber extraction was an obstacle to managing timber trees on cocoa farms. The exclusion of farmers from the timber market is an important constraint to managing timber trees on cocoa farms in Ghana and Côte d'Ivoire (Anglaaere et al. 2011; Ruf 2011) and this was often the reason why farmers were felling or burning high value timber trees in their cocoa plots (Ruf et al. 2006).

Consensus on compatibility of tree species with cocoa

In Côte d'Ivoire, despite the long-term promotion of full sun cocoa systems and the lack of information about compatible tree species for cocoa from the research and extension services, farmers shared common perceptions about the suitability of trees species for integrating with cocoa. Overall, most farmers considered most of the trees commonly found on farms to be compatible with cocoa but some species were considered more compatible than others. Amongst the most compatible species was A. altilis but this species was only present in one of the study locations (Kragui). Terminalia ivorensis, T. superba, $S$. campanulata and $R$. heudelotii were also generally mentioned as highly compatible with cocoa and have been previously identified as suitable for integrating with cocoa in Ghana (Asare 2005). They were valued by farmers for the quality of shade, soil fertility improvement and in the case of $S$. campanulata and $R$. heudelotii for their positive role in increasing soil moisture availability, especially in the dry season. The role of $S$. campanulata in increasing soil moisture has been previously recorded in Ghana (Anim-Kwapong and Osei-Bonsu 2009). Ricinodendron heudelotii is also known to root deeply, likely to reduce competition for water with cocoa, and because of the high market potential of its kernels, has been indentified as a promising tree species for domestication in West Africa (Tchoundjeu and Atangana 2007). The least compatible tree species were oil palm (E. guineensis) and mango ( $M$. indica) although mentioned by only $40 \%$ of farmers, suggesting the large divergence in responses probably arose from the different extent to 
which farmers were considering trade-offs when responding. In the case of oil palm, there was common knowledge that it provides a nesting environment for rodents and is competitive for nutrients and water but its cultural importance for nutrition explains why some farmers maintain oil palm in their cocoa fields despite its drawbacks. In the case of mango, present on $67 \%$ of cocoa fields, the importance for nutrition and income means that farmers tolerate individual trees in their fields, despite the trade-offs with cocoa production.

Species-specific knowledge

Farmers were aware that different tree species displayed different attributes that affected their compatibility with cocoa and their uses. For example, farmers said that $C$. pentandra, the tree most commonly identified as causing physical damage to cocoa or people from falling branches, was particularly problematic in this respect when old. As the most frequent forest tree relic found on cocoa farms, many trees were old, very tall and so difficult to prune. In terms of other species that cause damage, T. scleroxylon is a selfpruning tree from which branches can be expected to fall and Alstonia boonei and S. tracagantha are known to have brittle branches that break easily (Palla 2005; Orwa et al. 2009). It is clear that the issue of trees causing damage to cocoa is limited to a few species. The development and implementation of appropriate species-specific management guidelines could minimize risk of damage which may also be accepted by farmers as justifiable because of the economic value of the timber (Ryan et al. 2009).

Trees attracting rodents was relevant to a broader range of species but the most problematic tree was oil palm because the morphological characteristics of its fronds made it suitable for squirrels to nest in them. Other trees that particularly attracted rodents were $C$. pentandra and T. scleroxylon. Farmers explained that these trees frequently loose branches and limbs that open cavities that become ideal habitat for squirrels. Although cocoa pod damage by squirrels causes yield loss, farmers frequently mentioned that they hunted squirrels, which made a useful contribution to family nutrition. Given that the original forest fauna has largely disappeared, many farmers, especially national migrants, said that squirrels had become an important source of animal protein in the family diet.
Only seven, mainly fruit tree species were commonly identified as competitive for nutrients with cocoa. The most competitive species was unanimously $P$. guajava, followed by Piptadeniastrum africanum a leguminous timber species and fruit trees such as $C$. nitida and $C$. sinensis. Surprisingly, Albizia spp., although leguminous and known to improve soil, was considered to be competitive by almost half of the farmers.

Phytophthora megakarya is increasingly important in West Africa (Holmes et al. 2003), and has a variety of alternate host plants, notably native forest trees (Opoku et al. 2002). Ivorian farmers linked seven tree species with increased incidence of black pod disease, including C. nitida, P. guajava, T. scleroxylon, A. altilis, M. indica and C. pentandra. Opoku et al. (2002) have provided evidence of $P$. megakarya parasitism on Sterculia tracagantha and $R$. heudelotii but they found no visual evidence of higher infestation levels on cocoa plants nearer the host trees and concluded that it was unlikely that the presence of the identified host trees would have any significant influence on the levels of black pod disease on cocoa. In our survey, $8 \%$ of farmers identified S. tracagantha and $10 \%$ identified $R$. heudelotii as increasing black pod disease. Such effects may arise from the level and quality of shade affecting humidity rather than the host status of the tree (Schroth et al. 2000).

Scientific evidence has also shown that species taxonomically related to cocoa, i.e. members of the Sterculiaceae family, can share pests and diseases with cocoa. This is notably the case for mirids, one of the most important cocoa pests in West Africa (Schroth et al. 2000). Most farmers (79\%) in our survey identified $C$. nitida as an alternative host for mirids, concurring with technical information available (SATMACI 1984; Schroth et al. 2000), but this was the only member of the Sterculiaceae that they identified in this context. Sterculia tracagantha and Pterygota macrocarpa, for example, were not identified as alternate hosts for mirids and neither were most species of the Bombacaceae family, that have also been mentioned as possible alternate hosts (SATMACI 1984; Schroth et al. 2000). One exception was Bombax buonopense mentioned by only $10 \%$ of farmers. No farmers mentioned C. pentandra in this regard despite its prevalence in the area. On the other hand, $75 \%$ of farmers identified Citrus species as alternative hosts of mirids, concurring with previous information (Padi and Owusu 2003). 
Mistletoes (Tapinanthus spp.) are important parasitic plants affecting cocoa causing loss of cocoa tree vigor and yield decline, with heavy attacks sometimes causing cocoa mortality (Padi and Owusu 2003). Our results show that farmers identified fruit trees such as C. nitida, $M$. indica and $C$. reticulata as alternative hosts in addition to forest tree species such as $C$. pentandra, Holarrhena floribunda, Pycnanthus angolensis and T. scleroxylon, corroborating previous results showing these species to be alternative hosts of Tapinanthus spp. in Ghana (Phillips 1977). This knowledge was not evenly distributed amongst farmers. Despite the increasing threat of the CSSV in Côte d'Ivoire, only a few farmers were aware of the virus and the host status of tree species in their cocoa plots.

Certification and advice about integrating trees with cocoa

Engagement with eco-certified cooperatives was clearly an important source of advice about shade trees for protecting cocoa in the dry season. Only a minority (15\%) of non certified farmers had received advice about cocoa shade trees compared to $76 \%$ of certified farmers, still showing that almost a quarter of eco-certified farmers had not received any advice on trees. Eco-certification schemes principally operating through the Sustainable Agriculture Network (SAN) have put forward shade management criteria and indicators for cocoa farms as part of good cocoa management practices. In Côte d'Ivoire, farmers are required to maintain or plant 12 native species ha ${ }^{-1}$ and $40 \%$ canopy cover (SAN (Sustainable Agricultural Network) 2009). Our results show that both the number of tree species and the shade density in cocoa fields were well below certification requirements, even amongst certified farmers, consistent with the recent onset of certification in the area. Perhaps of greater concern was the large variation in knowledge amongst eco-certified farmers about both the number of trees and species required. Farmers only recalled eight species being recommended as shade trees for cocoa, dominated by Terminalia spp., despite the existence of an official list of 19 recommended species (SAN (Sustainable Agricultural Network) 2009). Although advice was concentrated on a limited list of species and had a clear influence on preferences shared by ecocertified farmers, overall, both eco-certified and non eco-certified farmers expressed a desire to use a broader diversity of trees to meet their needs for products and services.

\section{Conclusion}

Despite the cocoa frontier expanding at the expense of forest cover, and full sun cocoa being the predominant form of cultivation promoted over the last half century in Cote d'Ivoire, cocoa farms still contain a reservoir of forest tree species, including some of high conservation value. Farmers overwhelmingly want to have more trees on their farms, both to sustain their cocoa production and to diversify their livelihood, particularly in relation to their food security, as shown by the important presence of fruit trees in cocoa fields. Whether certified or not, farmers valued a variety of tree species in their cocoa fields because they believed that they protected cocoa from water stress in the dry season and improved soil fertility. Farmers were interested in integrating a diversity of tree species on their farms to meet their needs and had detailed knowledge about how different species affect a range of ecosystem services responsible for sustainable cocoa productivity, regardless of their ethnic origin or certification status. In addition there were notable knowledge gaps, particularly relating to trees as alternate hosts to pests and diseases such as Phytophtora spp. and CSSV. Assessing local knowledge about integrating trees with cocoa in the country remains a challenge because of the linguistic diversity of the ethnic groups involved and their diverse places of recent origin. Eliciting local knowledge would be the key next step in developing approaches to promoting tree diversity in cocoa. This would allow identification of gaps in knowledge that research and extension should address and help to refine current understanding of field, farm and landscape niches for different tree species. In the past, research recommendations for cocoa production in the region have often served as a barrier to farmer innovation instead of building on local knowledge and preferences and led at best to the promotion of a few key species rather than increasing tree diversity (Asare 2005). The importance of knowledge transfer between farmers and scientists to improve shade-tree management and to implement certification schemes for cocoa has been identified (Tscharntke et al. 2011) and has been instrumental in promoting diversity in coffee agroforestry (Soto-Pinto 
et al. 2007; Cerdan et al. 2012). It is unlikely that the conservation value of trees in cocoa systems will be maintained without some deliberate action, since as time goes on, the regeneration of forest species diversity is likely to decline (Robiglio and Sinclair 2011) and farmers will tend to preserve a limited set of species that most immediately meet their needs (Vaast et al. 2005; Harvey et al. 2011). The cocoa landscapes in the South-West of Côte d'Ivoire appear to be at a turning point. Their productivity is declining along with their conservation value. Both issues can be addressed by promoting appropriate tree diversity with good management practices, supported by a favorable policy environment, that includes security of land and tree tenure for farmers, certification schemes and better integration of producers in value chains to ensure higher economic returns to cocoa and other tree products. Integrated research embracing local knowledge, cocoa agronomy and ecosystem service provision is urgently required to achieve production and conservation objectives simultaneously.

Acknowledgments Funds for this research were provided by the Mars Vision for Change (V4C) project and from the CGIAR research programs on Forests, Trees and Agroforestry and Humid Tropics. The authors thank the V4C project team in Soubré, the field surveyors and the farmers for their collaboration during field visits and interviews.

Open Access This article is distributed under the terms of the Creative Commons Attribution License which permits any use, distribution, and reproduction in any medium, provided the original author(s) and the source are credited.

\section{References}

Anglaaere LC, Cobbina J, Sinclair FL, McDonald MA (2011) The effect of land use systems on tree diversity: farmer preference and species composition of cocoa-based agroecosystems in Ghana. Agroforest syst 81(3):249-265

Anim-Kwapong GJ, Osei-Bonsu K (2009) Potential of natural and improved fallow using indigenous trees to facilitate cacao replanting in Ghana. Agroforest syst 76(3):533-542

Asare R (2005) Cocoa agroforests in West Africa: a look at activities on preferred trees in the farming systems. Forest and Landscape Denmark (FLD) 77p

Asare R (2006) Learning about neighbour trees in cocoa growing systems: a manual for farmer trainers. Forest and landscape development and environment series 4. p 80

Assiri A, Yoro G, Deheuvels O, Kebe BI, Keli ZJ, Adiko A, Assa A (2009) Les caractéristiques agronomiques des vergers de cacaoyer (Theobroma cacao L.) en Côte d'Ivoire. J Anim Plant Sci 2(1):55-66

Barrios E, Sileshi G, Shepherd K, Sinclair FL (2012) Agroforestry and soil health: linking trees, soil biota and ecosystem services. In: Wall DH (ed) Soil ecology and ecosystem services. Oxford University Press, Oxford, pp 315-330

Bisseleua DHB, Missoup AD, Vidal S (2009) Biodiversity conservation, ecosystem functioning, and economic incentives under cocoa agroforestry intensification. Conserv Biol 23(5):1176-1184

Bos MM, Steffan-Dewenter I, Tscharntke T (2007) The contribution of cacao agroforests to the conservation of lower canopy ant and beetle diversity in Indonesia. Biodivers Conserv 16(8):2429-2444

Brou T (2010) Variabilité climatique, déforestation et dynamique agrodémographique en Côte d'Ivoire. Science et changements planétaires Sécheresse 21(4):327-329

Cerda R, Deheuvels O, Calvache D, Niehaus L, Saenz Y, kent J, Vilchez S, Villota A, Martinez C, Somarriba E (2014) Contribution of cocoa agroforestry systems to family income and domestic consumption: looking toward intensification. Agroforest syst (special cocoa issue)

Cerdan CR, Rebolledo MC, Soto-Pinto G, Rapidel B, Sinclair FL (2012) Local knowledge of impacts of tree cover on ecosystem services in smallholder coffee production systems. Agrofor Syst 110:119-130

Clough Y, Faust H, Tscharntke T (2009) Cacao boom and bust: sustainability of agroforests and opportunities for biodiversity conservation. Conserv Lett 2(5):197-205

CNRA (2011) Guide de la lutte contre la maladie du swollen shoot du cacaoyer en Cote d'Ivoire. Première edition, Centre National de Recherche Agronomique/Programme Cacao, p 39

Deheuvels O, Avelino J, Somarriba E, Malezieux E (2012) Vegetation structure and productivity in cocoa-based agroforestry systems in Talamanca, Costa Rica. Agric Ecosyst Environ 149:181-188

Duguma B, Gockowski J, Bakala J (2001) Smallholder cacao (Theobroma cacao Linn.) cultivation in agroforestry systems of West and Central Africa: challenges and opportunities. Agroforest syst 51(3):177-188

FIRCA (2008) Guide la régénération des vergers de cacaoyer ou de caféier en Côte d'Ivoire. République de Côte d'Ivoire, Le Fonds Interprofessionnel pour la Recherche et le Conseil Agricole, p 39

Franzen M, Mulder MB (2007) Ecological, economic and social perspectives on cocoa production worldwide. Biodivers Conserv 16(13):3835-3849

Gockowski J, Sonwa D (2011) Cocoa intensification scenarios and their predicted impact on $\mathrm{CO} 2$ emissions, biodiversity conservation, and rural livelihoods in the Guinea rain forest of West Africa. Environ Manage 48(2):307-321

Gockowski J, Weise S, Sonwa D, Tchatat M, Ngobo M (2004) "Conservation because it pays: shaded cocoa agroforests in West Africa." National Academy of Sciences in Washington DC on Feb 10 2004. (http://www.icraf.com/ treesandmarkets/inaforesta/documents/shaded_cocoa_ agroforests_in_w_africa.pdf) Accessed 24 Aug 2013

Harvey CA, Villanueva C, Esquivel H, Gómez R, Ibrahim M, Lopez M, Martinez J, Muñoz D, Restrepo C, Saénz JC, Villacís J, Sinclair FL (2011) Conservation value of 
dispersed tree cover threatened by pasture management. Forest Ecol Manage 261:1664-1674

Herzog F (1994) Multipurpose shade trees in coffee and cocoa plantations in Côte d'Ivoire. Agroforest syst 27:259-267

Holmes KA, Evans HC, Wayne S, Smith J (2003) Irvingia, a forest host of the cocoa black-pod pathogen, Phytophthora megakarya Cameroon. Plant Pathol 52(4):486-490

ICRAF (2011) Presentation Synoptique du Departement de Soubré. World Agroforestry Center Vision for Change Project, Internal Document

Isaac ME, Timmer VR, Quashie-Sam SJ (2007) Shade tree effects in an 8-year-old cocoa agroforestry system: biomass and nutrient diagnosis of Theobroma cacao by vector analysis. Nutr Cycl Agroecosyst 78(2):155-165

Jagoret P, Michel-Dounias I, Malézieux E (2011) Long-term dynamics of cocoa agroforests: a case study in central Cameroon. Agroforest syst 81(3):267-278

Jagoret P, Kwesseu J, Messie C, Michel-Dounias I, Malezieux E (2014) Farmers' assessment of the use value of agrobiodiversity in multispecies systems. An application to cocoa agroforests in central Cameroon. Agroforest syst (special cocoa issue)

Koko LK, Kassin KE, Yoro G, NGoran K, Yao-Kouamé A (2009) Corrélations entre le vieillissement précoce des cacaoyers et les caractéristiques morphopédologiques dans le sud-ouest de la Côte d'Ivoire. J Appl Biosci 24:1508-1519

Koko LK, Snoeck D, Lekadou TT, Assiri AA (2013) Cacao-fruit tree intercropping effects on cocoa yield, plant vigour and light interception in Côte d'Ivoire. Agroforest syst 87(5):1-10 (online 2013)

Leakey RRB, Tchoundjeu Z (2001) Diversification of tree crops: domestication of companion crops for poverty reduction and environmental services. Exp Agric 37:279-296

Léonard E, Ibo JG (1994) Appropriation et gestion de la rente forestière en Côte-d'Ivoire: La nature et l'homme en Afrique. Politique africaine 53:25-36

Mission économique, MINEFI-DGTPE (2005) Le Cacao en Côte d'Ivoire. Fiche de synthèse, Ambassade de France en Côte d'Ivoire. p 3

N'Goran K (1998) Reflections on a durable cacao production: the situation in the Ivory Coast, Africa. Paper presented at a workshop held in Panama, 3/30-4/2, 1998. Smithsonian Institution, Washington, D.C.

Nomo B, Madong BA, Sinclair FL (2008) Status of non-cocoa tree species in cocoa multistrata systems of Southern Cameroon. Int J Biol Sci 2:207-215

Obiri BD, Bright GA, McDonald MA, Anglaaere LC, Cobbina J (2007) Financial analysis of shaded cocoa in Ghana. Agroforest syst 71(2):139-149

OIPR, GTZ (2000) Flore du Parc national de Tai (Côte d'Ivoire). Manuel de reconnaissance des principales plantes. In: Kasparek Verlag (ed) Office Ivoirien des Parcs et Reserves. p 320

Oke DO, Odebiyi KA (2007) Traditional cocoa-based agroforestry and forest species conservation in Ondo State Nigeria. Agr ecosyst environ 122(3):305-311

Opoku IY, Akrofi AY, Appiah AA (2002) Shade trees are alternative hosts of the cocoa pathogen Phytophthora megakarya. Crop Prot 21(8):629-634
Orwa C, Mutua A, Kindt R, Jamnadass R, Simons A (2009) Agroforestree database: a tree reference and selection guide version 4.0. http://www.worldagroforestry.org/af/ treedb/. Accessed 5 July 2013

Oszwald J (2005) Dynamique des formations agroforestières en Côte d'Ivoire (depuis les années 1980 aux années 2000): suivi par télédétection et développement d'une approche cartographique. 2005. PhD Thesis. Universite de Lille, France

Padi B, Owusu GK (2003) Towards an Integrated Pest Management for Sustainable Cocoa Production in Ghana. Paper from workshop held in Panama, 3/30-4/2, 1998. Smithsonian institution, Washington D.C.

Palla F (2005) Alstonia boonei De Wild. [Internet] Record from PROTA4U. Louppe D, Oteng-Amoako AA, Brink M (eds) PROTA (Plant resources of tropical africa/Ressources végétales de l'Afrique tropicale), Wageningen, Netherlands. <http://www.prota4u.org/search.asp >. Accessed 5 July 2013

Phillips EJ (1977) Mistletoe on cocoa in Ghana. Ghana J Agric Sci 10:137-143

Rice RA, Greenberg R (2000) Cacao cultivation and the conservation of biological diversity. AMBIO J Hum Environ 29(3):167-173

Robiglio V, Sinclair FL (2011) Maintaining the conservation value of shifting cultivation landscapes requires spatially explicit interventions. Environ Manage 48:289-306

Rousseau GX, Deheuvels O, Rodriguez Arias I, Somarriba E (2012) Indicating soil quality in cacao-based agroforestry systems and old-growth forests: the potential of soil macrofauna assemblage. Ecol Ind 23:535-543

Ruf F (2011) The myth of complex cocoa agroforests: the case of Ghana. Hum Ecol 39(3):373-388

Ruf F, Konan A (2001) Replanting difficulties: what future for cocoa in Côte d'Ivoire? Ol Corps Gras Lipides 8:593-598

Ruf F, Zadi H (1998) Cocoa: from deforestation to reforestation. Paper from workshop on Shade Grown Cocoa held in Panama, 3/30-4/2, 1998. Smithsonian institution, Washington D.C.

Ruf F, Deheuvels O, Sarpong D (2006) Intensification in cocoa cropping systems: Is Agroforestry a solution for sustainability? The case of Manso Amenfi, Western Region, Ghana. In 15th International conference on cocoa research (1): 355-364

Ryan D, Bright GA, Somarriba E (2009) Damage and yield change in cocoa crops due to harvesting of timber shade trees in Talamanca, Costa Rica. Agroforest syst 77:97-106

Saj S, Jagoret P, Ngogue HT (2013) Carbon storage and density dynamics of associated trees in three contrasting Theobroma cacao agroforests of Central Cameroon. Agroforest Sys 87(6):1309-1320

SAN (Sustainable Agricultural Network) (2009) Interpretation guidelines - indicators for sustainable cocoa production in Ivory Coast, Sustainable Agriculture Program Rainforest Alliance, Costa Rica

SATMACI (1984) Manuel de cacaoculture. Societe d'Assistance Technique la Modernisation Agricole de la Côte d'Ivoire. Ministere de l'Agriculture. Abidjan, Avril 1984

Schroth G, Harvey CA (2007) Biodiversity conservation in cocoa production landscapes: an overview. Biodivers Conserv 16(8):2237-2244 
Schroth G, Krauss U, Gasparotto L, Aguilar JD, Vohland K (2000) Pests and diseases in agroforestry systems of the humid tropics. Agroforest syst 50(3):199-241

Somarriba E, Cerda R, Orozco L, Deheuvels O, Cifuentes M, Dávila H, Espin T, Mavisoy H, Ávila G, Alvarado E, Poveda V, Astorga C, Say E (2013) Carbon stocks in agroforestry systems with cocoa (Theobroma cacao L.) in Central America. Agr ecosyst environ 173:46-57

Sonwa DJ, Nkongmeneck BA, Weise SF, Tchatat M, Adesina AA, Janssens MJ (2007) Diversity of plants in cocoa agroforests in the humid forest zone of Southern Cameroon. Biodivers Conserv 16(8):2385-2400

Sonwa DJ, Weise SF, Schroth G, Janssens MJ, Shapiro H (2014) Market and Livelihoods demand implications on plant diversity management inside cocoa agroforest in forest landscape of West and Central Africa. Agroforest syst (special cocoa issue)

Soto-Pinto L, Villavaza-López V, Jiménez-Ferrer G, RamírezMarcial N, Montoya G, Sinclair FL (2007) The role of local knowledge in determining shade composition of multistrata coffee systems in Chiapas, Mexico. Biodivers Conserv 16:419-436

Tchoundjeu Z, Atangana AR (2007) Ricinodendron heudelotii (Baill.) Pierre ex Heckel. [Internet] Record from
PROTA4U. van der Vossen HAM, Mkamilo GS (eds) PROTA (Plant Resources of Tropical Africa/Ressources végétales de l'Afrique tropicale), Wageningen, Netherlands. <http://www.prota4u.org/search.asp $>$. Accessed 5 July 2013

Tscharntke T, Clough Y, Bhagwat SA, Buchori D, Faust H, Hertel D, Wanger TC (2011) Multifunctional shade-tree management in tropical agroforestry landscapes-a review. J Appl Ecol 48(3):619-629

Vaast P, Beer J, Harvey C, Harmand JM (2005) Environmental services of coffee agroforestry systems in Central America: a promising potential to improve the livelihoods of coffee farmers' communities. In: Integrated Management of Environmental Services in Human-Dominated Tropical Landscapes. CATIE, IV Henri A. Wallace Inter-American Scientific Conference Series, Turrialba, Costa Rica, pp 35-39

Wilkie P, Saridan A (1999) The limitations of vernacular names in an inventory study, Central Kalimantan, Indonesia. Biodivers conserv 8(11):1457-1467

World Cocoa Foundation (2012) Cocoa market update accessed online 6th Jan 2014 http://worldcocoafoundation.org/wpcontent/uploads/Cocoa-Market-Update-as-of-3.20.2012. pdf 